Economics Development Analysis Journal 6 (4) (2017)

\title{
Analysis of Asean's Shock in The Discourse on Establishing Asean Currency Unit (Acu)
}

\section{Susi Susanti ${ }^{凶}$}

Economics Development Department, Economics Faculty, Universitas Negeri Semarang

\begin{tabular}{l}
\hline Article History \\
\hline Article History: \\
Received Juny 2017 \\
Accepted August 2017 \\
Published November \\
2017 \\
\hline Keywords: \\
Asean Currency Unit, \\
Consumer Price Index \\
(CPI), Real GDP, Trade \\
Balance, Optimum \\
Currency Area, Vector \\
Error Correction Model \\
(VECM)
\end{tabular}

\begin{abstract}
The discourse of the establishment of ASEAN single currency is the vision of ASEAN in 2020 with the aim to facilitate the stabilization of the regional exchange rate. The region that will form a single currency must have the same trade pattern criteria, symmetrical macroeconomic shocks and similar development economics characteristics. However, the economics indicators of ASEAN region are still inbalances. This study aims to analyze the shocks response of economic indicators in ASEAN10. The variables in this research are Consumer Price Index (CPI), Real GDP and Trade Balance from ASEAN countries. This research model is Vector Error Correction Model. The are low correlation between Consumer Price Index (CPI), Real GDP and Trade Balance in ASEAN. The shock response from ASEAN countries to shocks that occurred in Singapore showed varying results and not symmetrical. This is shows that the requirement of formation of single currency has not been fulfilled. The result of the decomposition variant also shows that Singapore's economic turmoil is still dominantly influenced by internal conditions. However, the decomposition variant of GDP Rill shows that Laos has a higher role compared to Singapore due to the cooperative relationship between the two countries.
\end{abstract}

${ }^{凶}$ Corresponding Author:

Journal's Room, L Building, FE UNNES Sekaran

Gunungpati Semarang 50229, Indonesia

E-mail: susisusanti@gmail.com 


\section{INTRODUCTION}

The Association of Southeast Asian Nations (ASEAN) was formed on August 8, 1967 which originally consisted of five countries, namely Indonesia, Malaysia, Singapore, Thailand and the Philippines. Until 1999, ASEAN members continued to increase to become ten members.

Following the idea of integration in a region. Since 2015, ASEAN has established Asean Economic Community (AEC). Asean Economic Community is a form of regional economic integration with the goal of making Asean a single market and production base whereby the flow of goods, services, investment, labor, and the flow of free capital. The priority sectors of the AEC are agriculture, automotive, electronics, fisheries, wood products, air transport, e-ASEAN, health and tourism. (Ministry of Trade, 2015). The purpose of this cooperation is motivated by one of them is the Asian Financial Crisis that occurred in 1998. The crisis that cames from Thailand and then causing contagion effect to the whole of ASEAN region. (Harahap, 2013). Since then, regional financial cooperation in East Asia has been induced by gradual financial liberalization with increasing cross-border capital flows, establishing regional financial arrangements, and developing local currency bond markets (Park, 2017).

The follow-up of the economic integration taking place in Asean is the establishment of a single currency in accordance with the vision of ASEAN 2020.

The formation of a single currency is expected to facilitate the transaction and stabilization of the financial system in ASEAN. The background of the establishment is the flow of capital in and out of ASEAN countries has been open.

A country are free to invest to another country. In addition, the factor driving the formation of a single currency is the success of the Euro currency that managed to become the world's number two currency and an alternative when the dollar value is not stable. (Falianty, 2006). Mawar in Falianty (2006) said that countries that are part of the currency union will experience $100 \%$ higher trading flow compared to countries that are not members of the currency union. The growing interdependency among East Asian countries means that there is concern not only on the way their macroeconomic variables are linked across borders, but also on the way shocks are transmitted as a consequence (Hassan, 2017).

An area that will form a single currency must meet the criteria of the Optimum Currency Area (OCA) theory. This theory says that an optimal geographical scope with one currency type or multiple currencies in pegs must permanently meet certain criteria. These criteria include internal and external factor mobility, wages and labor. (Mundell in Kusuma, 2013).

Tabel 1. Asean Economic Indicator

\begin{tabular}{llll}
\hline Country & $\begin{array}{l}\text { Exchange } \\
\text { rate } \\
\text { towards } \\
\text { USD }\end{array}$ & $\begin{array}{l}\text { Inflation } \\
(\%)\end{array}$ & $\begin{array}{l}\text { NP } \\
\text { (million } \\
\text { US\$) }\end{array}$ \\
& 0,34 & 8,4 & $-1.886,2$ \\
\hline $\begin{array}{l}\text { Indonesia } \\
\text { Brunei }\end{array}$ & $-2,88$ & $-0,2$ & $6.987,6$ \\
Darussalam & & & \\
Singapura & -3.14 & 1,0 & $43.521,4$ \\
Laos & 1,68 & 4,2 & $-109,0$ \\
Kamboja & $-0,36$ & 3,9 & $-8.291,8$ \\
Thailand & 1,58 & 1,9 & $-378,7$ \\
Filipina & $-1,15$ & 4,2 & $-5.947,0$ \\
Myanmar & $-4,76$ & 1,0 & $-5.195,4$ \\
Vietnam & $-0,07$ & 4,1 & $2.405,9$ \\
Malaysia & $-3,17$ & 4,2 & $25.076,9$ \\
\hline
\end{tabular}

Source : WDI, 2016

Based on table 1, there is considerable imbalance or differences among ASEAN countries. Exchange rate indicators in ASEAN are almost depreciated.

The strengthening or weakening of the exchange rate is influenced by the balance of international trade and business. The inflation indicator shows Indonesia is experiencing very high inflation. This is caused by internal conditions in the country that is the policy of raising the

Brunei Darussalam, however, experienced a deflation of inflation control policy by pegging 
the Singapore dollar. While the trade balance indicator shows that almost all ASEAN countries have a balance deficit, except Brunei Darussalam, Singapore, Vietnam and Malaysia. Countries experiencing trade balance deficits show a high dependence on foreign imports.

Tabel 2. GDP per capita in ASEAN, current

\begin{tabular}{llll} 
& \multicolumn{2}{c}{ price (US\$) } \\
\hline Negara & 2005 & 2010 & 2015 \\
\hline $\begin{array}{l}\text { Brunei } \\
\text { Darussalam }\end{array}$ & 26.569 & 32.063 & 30.942 \\
Kamboja & 453 & 785 & 1.198 \\
Indonesia & 1.295 & 2.977 & 3.357 \\
Negara & 2005 & 2010 & 2015 \\
Laos & 511 & 1.079 & 1.831 \\
Malaysia & 5.511 & 8.772 & 9.657 \\
Myanmar & 237 & 811 & 1.246 \\
Filipina & 1.209 & 2.147 & 2.850 \\
Singapura & 29.866 & 46.570 & 52.744 \\
Thailand & 2.909 & 5.071 & 5.737 \\
Vietnam & 701 & 1.338 & 2.109 \\
\hline
\end{tabular}

Sumber :Asean Statistical Yearbook,2015

Based on table 2, the per capita GDP inequality in ASEAN is high. This is seen from the GDP per-capita gap between countries in ASEAN like Singapore and Brunei Darussalam with GDP per capita of Cambodia. Indicators of income per capita can show the level of welfare of the population in the country. Based on table 2 it can be concluded that broadly the level of welfare of the population in ASEAN is unbalanced.

Based on information from tables 1 and 2, it shows that macroeconomic indicators inequality among ASEAN countries is still considerable. Various efforts were made by ASEAN to protect regional cooperation in the region such as ASEAN Economic Community, ASEAN Political Security Community and ASEAN Socio Cultural Community. Prior to establishing the AEC community, ASEAN has also carried out the integration of PTA and AFTA. The discourse on the establishment of Asean Currency Unit aims to facilitate transactions and facilitate integration in ASEAN. However, the imbalance that occurs in ASEAN is an obstacle in the effort to form a single currency.

\section{RESEARCH METHOD}

This research belongs to quantitative research. The type of data used is secondary data in quarterly time series from January 2002 to December 2015. Variables used are Consumer Price Index (CPI), Real GDP Growth and Trade Balance.

The analytical method in this research is Vector Error Correction Model (VECM) using EViews 8 tools. The test that must be passed in VECM method is Pre-Estimation Test consisting of unit root test / stationary test, lag length test, cointegration test and granger causality test. After the pre-estimated test, then VECM test is done to see the short-term and long-term relationship. (Setiawan and Karsinah, 2016). Long-term and short-term relationships are made on Consumer Price Index variables, Real GDP and Trade Balance. The impulse response function was then performed to see the response of ASEAN shocks to shocks that occurred in the country benchmark, Singapore. Furthermore, the last test is forecast error variance decomposition to see the magnitude of the influence of each country in influencing the shocks that occur in the country benchmark, Singapore.

The model used in this study consists of three models, namely the Consumer Price Index (CPI) model, Real GDP model and Trade Balance model.

1. IHKsgp $=\beta 0+\beta 1 \mathrm{IHKbrunei}+\beta 2 \mathrm{IHKkbj}$ $+\beta 3$ IHKindo $+\beta 4$ IHKlaos $+\beta 5$ IHKmly $+\beta 6$ IHKmyn $+\beta 7$ IHKflp $+\beta 8$ IHKthl $+\beta 9$ IHKvie $+\varepsilon 2$ t. .

2. GDPsgp $=\beta 0+\beta 1$ GDPbrunei $+\beta 2$ GDPkbj $+\beta 3$ GDPindo $+\beta 4$ GDPlaos $+\beta 5$ GDPmly $+\beta 6$ GDPmyn $+\beta 7$ GDPflp $+\beta 8$ GDPth $1+\beta 9$ GDPvie+ $+\varepsilon 1$.

3. $\mathrm{NPsgp}=\beta 0+\beta 1 \mathrm{NPbrunei}+\beta 2 \mathrm{NPkbj}$ $+\beta 3$ NPindo $+\beta 4$ NPlaos $+\beta 5 \mathrm{NPmly}$ $+\beta 6$ NPmyn $+\beta 7$ NPflp $+\beta 8$ NPth $1+\beta 9$ NPvie $+\varepsilon 3 \mathrm{t}$ 
The test method used for stationary test is the Philips-Perron test with a real level of ten percent. Apaila t-PP value is more negative than the critical value of Mac Kinnon, then the data has been stationary (does not contain the root of the unit).

Table 3. Unit Root Test for IHK

\begin{tabular}{|c|c|c|c|c|}
\hline \multirow[t]{2}{*}{ Variable } & \multicolumn{2}{|l|}{ PP Value } & \multicolumn{2}{|c|}{$\begin{array}{l}\text { Critical } \\
\text { MacKinnon } \\
\text { (significancE) } \\
10 \% \text { ) }\end{array}$} \\
\hline & Level & $\begin{array}{l}\text { First } \\
\text { Difference }\end{array}$ & Level & $\begin{array}{l}\text { First } \\
\text { Difference }\end{array}$ \\
\hline Brunei & - & -7.219121 & - & -3.176618 \\
\hline Darussalam & 1.196039 & & 3.175693 & \\
\hline Kamboja & $\begin{array}{l}- \\
2.096511\end{array}$ & -4.723284 & 3.175693 & -3.176618 \\
\hline Indonesia & $\begin{array}{l}- \\
2.772995\end{array}$ & -7.381248 & $\begin{array}{l}- \\
3.175693\end{array}$ & -3.176618 \\
\hline Laos & $\begin{array}{l}- \\
2.933379\end{array}$ & -6.310469 & $\begin{array}{l}- \\
3.175693\end{array}$ & -3.176618 \\
\hline Malaysia & $\begin{array}{l}- \\
3.095050\end{array}$ & -6.796016 & $\begin{array}{l}- \\
3.175693\end{array}$ & -3.176618 \\
\hline Myanmar & $\begin{array}{l}- \\
1.819642\end{array}$ & -4.234936 & $\begin{array}{l}- \\
3.175693\end{array}$ & -3.176618 \\
\hline Filipina & - 2.366605 & -4.436519 & $\begin{array}{l}- \\
3.175693\end{array}$ & -3.176618 \\
\hline Singapura & $\begin{array}{l}- \\
1.988212\end{array}$ & -4.555253 & $\begin{array}{l}- \\
3.175693\end{array}$ & -3.176618 \\
\hline Thailand & $\begin{array}{l}- \\
1.675194\end{array}$ & -6.517450 & $\begin{array}{l}- \\
3.175693\end{array}$ & -3.176618 \\
\hline Vietnam & $\begin{array}{l}- \\
2.224276\end{array}$ & -3.260420 & $\begin{array}{l}- \\
3.175693\end{array}$ & -3.176618 \\
\hline
\end{tabular}

Source : IFS data, processed

Table 3 shows non-stationary CPI data at the level level so it needs to be tested at first level difference. However, in the first difference test, all CPI data has been stationary.

Tabel 4 Unit Root Test result for GDP (nominal price)

\begin{tabular}{lcccc}
\hline Variable & \multicolumn{2}{c}{ PP value } & \multicolumn{2}{c}{$\begin{array}{c}\text { MacKinnon Critical } \\
\text { Value } \\
\text { (significance 10\%) }\end{array}$} \\
\cline { 2 - 5 } Brunei & Level & $\begin{array}{c}\text { First } \\
\text { Difference }\end{array}$ & Level & $\begin{array}{c}\text { First } \\
\text { Difference }\end{array}$ \\
\cline { 2 - 5 } Darussalam & -4.050384 & -20.25995 & - & -3.176618 \\
Kamboja & -3.099389 & -10.42669 & -3.175693 & \\
& & & -3.175693 & -3.176618 \\
Indonesia & -3.689613 & -9.022273 & -3.175693 & -3.176618 \\
Laos & -2.675921 & -5.244620 & -3.175693 & -3.176618 \\
Malaysia & -3.463189 & -4.522068 & -3.175693 & -3.176618 \\
Myanmar & -2.921882 & -3.854910 & -3.175693 & -3.176618 \\
Filipina & -3.506192 & -7.114392 & -3.175693 & -3.176618 \\
Singapura & -3.517651 & -6.947505 & -3.175693 & -3.176618 \\
Thailand & -4.659222 & -9.444732 & -3.175693 & -3.176618 \\
Vietnam & -1.651474 & -3.910319 & -3.175693 & -3.176618 \\
\hline Source $:$ IFS data & processed & &
\end{tabular}

Source : IFS data, processed
Tabel 5. Unit root test for Balance of Trade

Tabel 5 Unit root test for Balance of Trade

\begin{tabular}{|c|c|c|c|c|}
\hline \multirow[t]{2}{*}{ Variable } & \multicolumn{2}{|c|}{ PP value } & \multicolumn{2}{|c|}{$\begin{array}{l}\text { MacKinnon Critical } \\
\text { Value } \\
\text { (significance } 10 \% \text { ) }\end{array}$} \\
\hline & Level & $\begin{array}{c}\text { First } \\
\text { Difference }\end{array}$ & Level & $\begin{array}{c}\text { First } \\
\text { Difference }\end{array}$ \\
\hline $\begin{array}{l}\text { Brunei } \\
\text { Darussalam }\end{array}$ & 0.266606 & -3.642433 & -3.175693 & 3.176618 \\
\hline Kamboja & $\overline{2} .129310$ & 4.297558 & 3.175693 & -3.176618 \\
\hline Indonesia & 3.139382 & -9.406059 & -3.175693 & -3.176618 \\
\hline Laos & $\overline{0} .906062$ & -7.387957 & -3.175693 & -3.176618 \\
\hline Malaysia & $\overline{3.067648}$ & -16.76453 & -3.175693 & -3.176618 \\
\hline Myanmar & $\overline{3} .968852$ & -26.33621 & -3.175693 & -3.176618 \\
\hline Filipina & $\overline{5} .154612$ & -14.42384 & -3.175693 & -3.176618 \\
\hline Singapura & 3.394968 & -9.359715 & -3.175693 & -3.176618 \\
\hline Thailand & 2.878527 & -10.02915 & -3.175693 & -3.176618 \\
\hline Vietnam & 3,467295 & -16.54306 & -3.175693 & -3.176618 \\
\hline
\end{tabular}

Table 5 shows the results of the root test of the trade balance unit at the level level still contains the root of the unit so that it is necessary to test at the first difference level. The test results at the first difference level indicate the data has been stationary.

\section{RESULTS AND DISCUSSION}

Short-term estimates of the Consumer Price Index (CPI) indicate that the increase in prices occurring in nine ASEAN countries has no significant relationship with inflation in Singapore. This is due to the short time-lag that has not shown its relationship with Singapore. While the correlation in the growth of Real GDP Singapore shown by the state of Brunei Darussalam and Malaysia. This means that the national income fluctuation in both countries in the short term has a strong correlation with the national income fluctuations that occurred in Singapore. However, on the results of the estimated trade balance there is absolutely no country that indicates a correlation with Singapore. This indicates that the trade surplus or deficit in nine countries in the ASEAN region will not be related to trading activities in Singapore. 
Based on these estimates, both in the long term and in the short term show a low correlation on economic indicators in ASEAN with benchmark countries which is Singapore. This low correlation indicates a lack of integration and strong cooperation within the ASEAN region.

This means that the economic integration that has been running in ASEAN has not achieved maximum results although at present, ASEAN has reached a stage of mature integration to form the ASEAN Economic Community (MEA). This looks from ASEAN's total trade data that indicates ASEAN is more engaged in trading activities with extra countries of ASEAN or non-ASEAN countries. The tendency of more ASEAN countries to trade with this extra-ASEAN country is in line with international trade theory where the state will seek profit by exporting goods that have small absolute losses and importing goods with greater absolute losses.

The results of this study are in accordance with research conducted by Ridha Subagja and Mubarok (2015) which concluded that the correlation of economic indicators among countries in ASEAN is very low. This result is also reinforced by research conducted by Mohseni and Azali (2014) that the formation of a single currency will cost a lot and is difficult to develop due to low correlation and the existence of differences in monetary policy of each country. Long-term relationships in the Consumer Price Index (CPI) variables show that in the long term, there are seven countries, namely Brunei Darussalam, Cambodia, Laos, Malaysia, Myanmar, Thailand and Vietnam with significant links with Singapore. While the two countries namely Indonesia and the Philippines have no significant relationship with the Consumer Price Index (CPI) in Singapore. This means that in the long term, price increases in Indonesia and the Philippines are not related to inflation in Singapore.

While the real estimate of real GDP of ASEAN countries on real GDP of Singapore in the long run shows that only Indonesia and Malaysia who have no significant relationship with the growth of Real GDP in Singapore. The phenomenon of an increase or decrease in real GDP in both countries is not related to the real GDP of Singapore. In addition to Real GDP, another economic indicator is the trade balance that shows the net export conditions of each ASEAN country. The long-term estimates of the trade balance show that there are two countries, Laos and Myanmar whose trading activities have no connection with Singapore trade. This indicates that the trade turmoil of Laos and Myanmar does not have a strong correlation with the trade turmoil in Singapore.

Based on these results, ASEAN economic conditions in the long run show mixed results from each economic indicator and there is no relationship that is equally strong from various countries. This result is contrary to the optimum theory of currency area which states that the requirement of formation of single currency among them is a strong correlation of each member country. However, the results of tests using the long-term Vector Error Correction Model (VECM) show results that are not yet compliant with the requirement.

A low correlation in the long term indicates that within the ASEAN region, the existing linkages and integration have not worked out optimally. The results of this study are in accordance with the research undertaken by Subagja and Mubarok (2015) which states that there is no economic variables that have a strong relationship or correlation between ASEAN countries so that the capability of ASEAN to form a single currency has not been fulfilled and the single currency can not be formed .

Impulse Response Function, the impulse response function indicates the shock response from all ASEAN countries to the shocks that occurred in Singapore. Countries that respond positively to inflation shocks in Singapore are Brunei Darussalam, Cambodia, Indonesia, Malaysia, the Philippines, Singapore, Thailand and Vietnam. While countries that respond negatively are Laos and Myanmar. These results indicate that the Consumer Price Index, which is a proxy of the inflationary conditions in each ASEAN country, does not have a similar pattern 
of shocks in the event of a shock in another country.

The result of impulse response function of real GDP growth shows a variety of shocks. Countries that respond to positive shocks in Singapore are Indonesia, Laos, Malaysia, Philippines, Singapore and Thailand. While countries that respond negatively are Brunei Darussalam, Cambodia, Myanmar and Vietnam. The response shown in real GDP shocks also produces asymmetric shocks. However, the time lag required by each country to adjust to real GDP shocks in Singapore is relatively fast. The response to real GDP will be related to the results of the trade balance test because net export is one component of real GDP.

The result of impulse response function test on the ASEAN trade balance on the balance sheet shock in Singapore also shows the result that has not symmetric. This is marked by the presence of two countries that respond negatively to the volatility of trade in Singapore, namely the Philippines and Thailand. If Singapore experiences an increase in trade balance surplus, then experienced by the Philippines and Thailand is the increasing deficit of trade balance. This means that import dependence with Singapore in both countries is high. Adjustment of each ASEAN country to shocks in Singapore takes a relatively long time. Until the 40th quarter there are still countries with an unstable shock response.

Optimum Currency Area Theory (OCA) states that one of the requirements of the formation of a single currency is a similar pattern of macroeconomic shocks, but when viewed from the results of impulse response function it can be concluded that ASEAN countries have not met these requirements from inflation shocks, real GDP or balance trading. Asymmetrical shocks that occur in ASEAN is in accordance with research conducted by Kusuma and Putranto (2010) which states that the intensity of trade is one cause of variations in inter-regional shocks in the region. Trade intensity in ASEAN is mostly done with the extra countries of ASEAN indicated by the low correlation between ASEAN countries. In addition, unexpected disturbances can also affect the national output of a country so that a country is different from others (Frankel and Musa, 1980 in Kusuma and Putranto, 2010).

Variance Decomposition, the result of variance decomposition of CPI variable shows contribution of inflation condition in a country to other country. This study shows that inflation conditions in Singapore within 5 years and 10 years are influenced by conditions from within the country. This condition is shown by a more stable and low rate of inflation compared to other ASEAN countries. The low inflation rate is due to stable commodity prices in Singapore. This is due to Singapore's stronger and more developed economy compared to other ASEAN countries. The strong economy in Singapore can be seen from the national income and income per capita of its people.

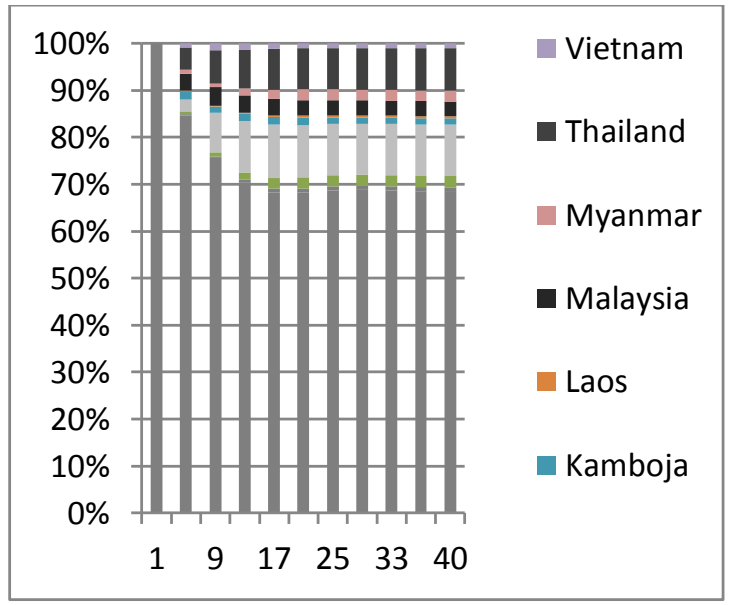

Figure 1. FEVD IHK Asean

Based on the variance decomposition of real GDP, the contribution to Real GDP in Singapore comes from the small country of Laos, which has a low income per capita. This means that the national income shocks in Laos have a greater impact than the conditions in Singapore itself. This condition is caused by a cooperation agreement between Laos and Singapore considering Laos is a liaison between Singapore and China. In addition to Singapore's liaison with China, Laos is a liaison country of ASEAN countries with China (landlink). This is in line with the neo-classical growth theory proposed by 
Harrod-Domar that focuses on the role of investment in the process of economic growth where investment can create income and investment that can enlarge the capacity of the economy by increasing capital stock.

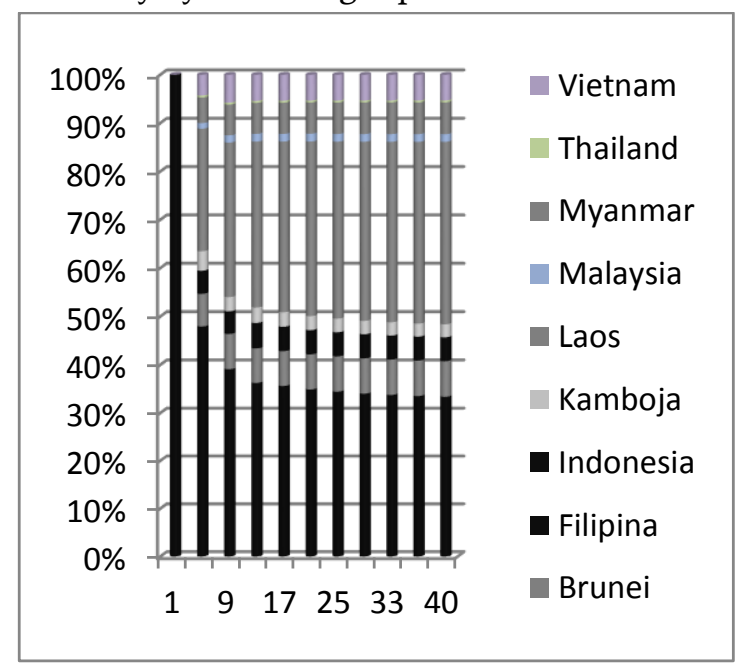

Figure 2. FEVD ASEAN Nominal GDP

While the variance decomposition of the trade balance shows the country that gives the highest contribution to the fluctuation of the fluctuation of Singapore's trade balance that comes from Singapore internal shocks.

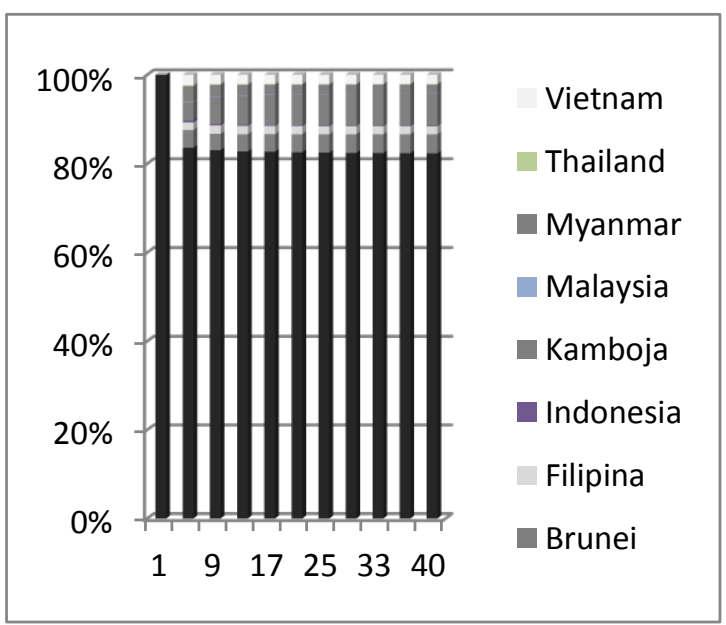

Figure 3. ASEAN FEVD Balance of Trade

The result of variance docomposition shows that in the period of 5 years to 10 years, the economic condition occurring in Singapore is still dominantly influenced from internal internal conditions. This means that contribution and correlation between ASEAN countries is still low.
This condition indicates a lack of integration in ASEAN so that the correlation between countries and the response to shocks is still asymmetrical. Based on the exposure of these results, macroeconomic variables in ASEAN, namely inflation, real GDP and trade balance show that there is no similar pattern of shocks and strong linkages of each ASEAN country.

Over a period of 10 years, there are still some countries that have not been stable in the face of shocks that occurred in Singapore. This indicates that ASEAN has not been able to control the economy in each country.

This is in accordance with the research of Kusuma and Putranto (2010) which concluded that ASEAN countries are not suitable to form a monetary union under the optimum concept of currency area in relation to the asymmetric shock fusion. In addition, research conducted by Mohseni and Azali (2014) concluded that an area that has not experienced a symmetric shock can not be applied to a single currency. These countries must improve their economic situation to join and form a single currency. Therefore, within 10 years ASEAN can not apply single currency because one of the requirements of Optimum Currency Area Theory can not be fulfilled.

\section{CONCLUSION}

Based on the above explanation, the conclusion of this study is the response of shocks that occurred in the ASEAN-10 of the CPI indicator, Real GDP and Trade Balance still showed mixed results or not yet symmetrical. In addition, each country in Asean has not been able to show an optimal relationship. This indicates a low correlation due to the lack of optimal integration within the Asean region itself. The phenomenon that occurs in Asean is not in accordance with the criteria of optimum theory of currency area so that the formation of single currency in Asean can not be done until ten years into the future. Need for strengthening of trade cooperation and openness of intraASEAN.

A single market with no common monetary polic 
y could lead to imbalances and misalignments rel ated to financial instability (e.g., multiplication of contagion and spillover effects, beggar-thy-neighbor exchange rate policies, and non-desirable arbitrage capital flows because of differences in inflation levels and interest rates) (Vinokurov, 2017).

\section{REFERENCES}

Achsani, Noer Azam, et al. (2013). The Feasibility of ASEAN + 6 Single Currency: A Vector Error Corection Model. ASEAN Journal of Economics, Management and Accounting1 (1): 23-47. Bogor: Bogor Agricultural University

Alvarado, Sylvia. (2014). Analysis of the Optimum Currency Area for ASEAN and ASEAN +3. Journal of US-China Public Administration, Vol 11, No. 12.995-1004. Ecuador: Universidad Andina Simon Bolivar

Ariefianto Moch Doddy and Perry Warjiyo. (2010). Joint Movement of ASEAN Currency 4 Period 1997-2005: An Application of Optimal Currency Area Theory by Using the Vector Error Correction Model. Bulletin of Monetary Economy, April 2010. Jakarta: Bank Indonesia

ASEAN Secretariat. (2016). ASEAN Statistical Yearbook 2015. Jakarta: ASEAN

Directorate General of National Export Development. (2015). Opportunities and Challenges of Indonesia ASEAN Free Market, Export News Edition January 2015. Jakarta: Ministry of Commerce RI

Falianty, Telisa Aulia. (2006). Endogenity of the Optimum Currency Area Indicator: Empirical Study in ASEAN Countries. Journal of Economics and Development of Indonesia Vol. VI No.02, 2006 January pp. 1-28. Depok: University of Indonesia

Harahap, Siti Romida. (2013). Early Detection of Indonesia's Exchange Rate Crisis: Identify Macro Economic Variables. Jurnal Ekonomi dan Kebijakan. 6 (1) (2013): 17-18. Semarang: Semarang State University

Hassan, B. I., Azali, M., Chin, L., Saini, W.N. W. 2017. Macroeconomic linkages and international shock transmissions in East Asia: A global vector autoregressive approach. Cogent Economics \& Finance, 5(1).

Kusuma, Dimas Bagus Wiranata and Arief Dwi Putranto. (2010). Implementation of Optimum Currency Area Criteria and Volatility: Case Study of ASEAN5 + 3. Bulletin of Monetary and Banking Economy. Malaysia: International Islamic University Malaysia

Kusuma, Dimas Bagus Wiranata., Et al. (2013). The Role of ASEAN Exchange Rate Units (AERU) for ASEAN-5 Monetary Integration: An Optimum Currency Area Criteria. Bulletin of Monetary and Banking Economy. Jakarta: Bank Indonesia

Mohseni, Reza Moosavi and M. Azali. (2014). Monetary Integration and Optimum Currency Area in ASEAN + 3: What We Need foa a New Framework? International Journal of Economics and Financial, Issues Vol. 4 No. 2, 2014, pp.277-285. Selangore: Universiti Putra Malaysia

Park, Youg Joon. (2017). Strengthening ASEAN+3 Regional Financial Arrangements: A New Framework Beyond CMIM. East Asian Economic Review 21(1) 59-80.

Setiawan, Rifky Yudi and Karsinah. (2016). Mechanism of Monetary Policy Transmission in Inflation and Economic Growth Influence in Indonesia. Economics Development Analysis Journal. EDAJ 5 (4) (2016). Semarang: Semarang State University

Subagja, Ridho and Syahid Irfan Mubarok. (2015). Economic Capacity Analysis of ASEAN Member Countries in the Formation of a Common Currency Formation. Study Vol.20 No. September 3, 2015 p. 241-254. Bandung: Padjadjaran University.

Vinokurov, Evgeny., Korshunov, Dmitry., Demidenko, Mikhail., Kovacs, Mihaly. (2017). Customs unions, currency crises, and monetary policy coordination: The case of the Eurasian Economic Union. Russian Journal of Economics 3, 280-295 